\title{
Comparative Assesment of Standalone Solar Photovoltaic Inverter using Proteus and MATLAB Simulink Software
}

\author{
Muhammad Awais ${ }^{1}$, Muhammad Anees ${ }^{2}$, Umair Younas ${ }^{3}$, Ahmet Afsin Kulaksiz ${ }^{4 *}$ \\ ${ }^{1}$ COMSATS University Islamabad, Dept of Electrical \& Electronics Engineering, Abbottabad, Pakistan, (ORCID: 0000-0002-0361-8354), awais.twin@gmail.com \\ ${ }^{2}$ COMSATS University Islamabad, Dept of Electrical \& Electronics Engineering, Abbottabad, Pakistan, (ORCID: 0000-0003-2875-4923), anees.twin@gmail.com \\ ${ }^{3}$ Konya Technical University, Department of Electrical \& Electronics Engineering, Konya, Turkey, (ORCID: 0000- 0003-2712-3601), umair.ciitatd@gmail.com \\ 4* Konya Technical University, Department of Electrical \& Electronics Engineering, Konya, Turkey, (ORCID: 0000-0003-3216-8185), aakulaksiz@ktun.edu.tr
}

(2nd International Conference on Computer, Electrical and Electronic Sciences ICCEES 2021, September 1-3, 2021)

(DOI: 10.31590/ejosat.1005660)

ATIF/REFERENCE: Awais, M., Anees, M., Younas, U. \& Kulaksiz, A. A. (2021). Comparative Assesment of Standalone Solar Photovoltaic Inverter using Proteus and MATLAB Simulink Software. European Journal of Science and Technology, (30), 6-11.

\begin{abstract}
Majority of the rising global energy demand is currently dependent on the conventional energy sources like coal, natural gas and fossil fuels etc. However, the conventional energy sources are depleting with time and the price of these sources is also increasing. Therefore, the deployment of renewable energy including solar PV, wind farms, biodiesel and biogas etc. are the need of the modern electric utility. Among renewables, the solar energy is the most abundant, geographically rich, clean, and noiseless energy source. Despite the various advantages of the solar energy, the lower efficiency of the solar panel and electronic conversion losses limits its applications. Therefore, this paper proposed the sinusoidal pulse width modulation based full bridge DC-AC inverter with higher efficiency is designed for the solar PV system. In order to enhance the accuracy, the simulation is performed in Proteus and Simulink MATLAB software. The accuracy and efficiency of the inverter is compared through the simulation results.
\end{abstract}

Keywords: Solar Photovoltaic, DC-AC Inverter, Pulse Width Modulation, RLC circuit, Transformer.

\section{Proteus ve MATLAB Simulink Yazılımı Kullanılarak Bağımsız Solar Fotovoltaik İnverterin Karşılaştırmalı Değerlendirilmesi}

$\ddot{\mathbf{O z}}$

Artan küresel enerji talebinin büyük bir kısmı şu anda kömür, doğal gaz ve fosil yakıtlar gibi konvansiyonel enerji kaynaklarına bağımlıdır. Ancak konvansiyonel enerji kaynakları zamanla tükenmekte ve bu kaynakların fiyatları da artmaktadır. Bu nedenle, güneş $\mathrm{PV}$, rüzgar çiftlikleri, biyodizel ve biyogaz vb. dahil olmak üzere yenilenebilir enerjinin yaygınlaştırılması, modern elektrik şirketlerinin ihtiyacıdır. Yenilenebilir enerji kaynakları arasında güneş enerjisi en bol bulunan, coğrafi olarak en zengin, temiz ve gürültüsüz enerji kaynağıdır. Güneş enerjisinin çeşitli avantajlarına rağmen, güneş panelinin nispeten düşük verimliliği ve elektronik dönüşüm kayıpları, uygulamalarını sınırlandırmaktadır. Bu nedenle, bu makalede güneş PV sistemi için daha yüksek verimliliğe sahip sinüzoidal darbe genişlik modülasyonu tabanlı tam köprü DC-AC evirici tasarlamıştır. Doğruluğu artırmak için simülasyon Proteus ve Simulink MATLAB yazılımlarında gerçekleştirilmiştir. Simülasyon sonuçları ile inverterin doğruluğu ve verimliliği karşılaştırılmıştır.

Anahtar Kelimeler: Solar Fotovoltaik, DC-AC İnverter, Darbe Genişlik Modülasyonu, RLC devresi, Transformatör.

\footnotetext{
*Corresponding Author: aakulaksiz@ktun.edu.tr
} 


\section{Introduction}

The The global energy demand is increasing rapidly due to urbanization and industrialization. The commonly used conventional energy sources (CES) are; fossil fuels, coal, nuclear energy and natural gas etc. The rising price of the fossil fuels, increasing environmental emissions, depleting nature of CES pose various challenges to the energy market. Considering the aforesaid demerits of the CES, the clean and economic Renewable Energy Sources (RES) like; solar photovoltaic (PV), wind energy, biogas, and geothermal etc are the intense need of the global energy society (Kumar, Singh, and others 2018). Among renewables, the solar energy is the most economical, viable, noiseless and geographically active energy source (Mertens n.d.). Solar PV can be used everywhere irrespective of the geographical location at mountains, oceans, forest, and cities etc. Despite various benefits of the solar PV energy, the lower efficiency of the solar panel, conversion losses and the DC output of the panel limits its applications. Therefore, efficient inverters with lower switching losses and effective total harmonic distortions are required to get the desired $220 \mathrm{~V} \mathrm{AC}$ voltage for residential applications.

In literature, various research methodologies have been adopted to increase the efficiency of the solar panel. The authors in ( $\mathrm{Li}$ and Chou 2004) adopted the load matching strategy to improve the efficiency and power utilization of the solar cell. To receive more irradiation from the sun, various trackers are reviewed by the authors in (Mousazadeh et al. 2009). Likewise, the combination of sun tracker strategy and maximum power point (MPP) extraction methodology is used in (Taherbaneh et al. 2010) and (System 2016). The authors in (Alhafadhi and Teh 2020) reviewed various modulation techniques to reduce the harmonic elimination in solar PV systems (Younas 2019). Likewise, half bridge inverter based control is designed for solar PV system by the authors in (Sastry et al. 2014). In this paper, sinusoidal pulse width modulation (SPWM) based full bridge inverter is designed for the standalone PV system. The proposed model is simulated in Proteus and MATLAB software. The $12 \mathrm{~V}$ DC voltage from the solar panel is provided to the proposed inverter and the $220 \mathrm{~V} \mathrm{AC}$ output is collected at the output of the inverter. The main components used in both softwares are; DC source (solar PV output), full bridge inverter, RLC resonant circuit (square wave to sine wave converter) and step up transformer (boost up the inverted AC voltage). The MATLAB software generates variable pulses based on SPWM while, proteus use fixed modulation based on time delay circuit to turn $\mathrm{ON}$ and OFF the corresponding switches. The rest of the paper is structured as follows:

The section II explained the design of the solar PV cell. Section III describes sinusoidal PWM for the proposed solar system. Section IV is based on the working of the full bridge inverter. Section V is comprised of the simulation results accomplished in Proteus and MATLAB software for standalone PV system. Section VI concludes the paper in the light of future work by showing the simulation outcomes that is followed by the references.

\section{Material and Method}

\subsection{Solar Photovoltaic Design}

The solar PV cell is manufactured using the semiconductor material like cadmium and gallium etc. The solar cell converts e-ISSN: 2148-2683 the sunlight into electricity using photoelectric effect. In photoelectric effect, the sunlight emits the electrons from the semiconductor the flow of electrons is dependent on the strength of the sunlight. Hence, the output of the solar cell is dependent on the nonlinear behaviour of the environmental conditions like; temperature and solar irradiance. To get the desired higher output voltage and current, the parallel and series combination of PV cells is used to form a single array (Younas, Akdemir, and Kulaksiz n.d.). The total solar output current is the addition of the individual currents of the cells.

The PV equivalent model is presented in Fig 1 (Younas et al. n.d.). The key parameters mentioned in the equivalent circuit as listed by the authors in (Younas 2019) are; I is the output terminal current that is equal to the $\mathrm{I}_{\mathrm{L}}$ the sunlight dependent current, $I_{d}$ is diode current and $I_{\text {sh }}$ shunt leakage current. The series resistance is represented $R_{s}$ that signify the internal resistance of the PV circuit for the flow of the current.

The output current $\mathrm{I}$ is determined by applying KCL on the solar cell equivalent circuit as presented in Eq. (1). Where $I_{p h}$ is written in Eq. (2),

$\mathrm{I}=\mathrm{I}_{\mathrm{ph}}-\left(\mathrm{I}_{\mathrm{d}}+\mathrm{I}_{\mathrm{sh}}\right)$

$\mathrm{I}_{\mathrm{ph}}=\left(\mathrm{I}_{\mathrm{scr}}+\mathrm{ki} \Delta \mathrm{T}\right) \frac{\mathrm{G}}{\mathrm{Gr}}$

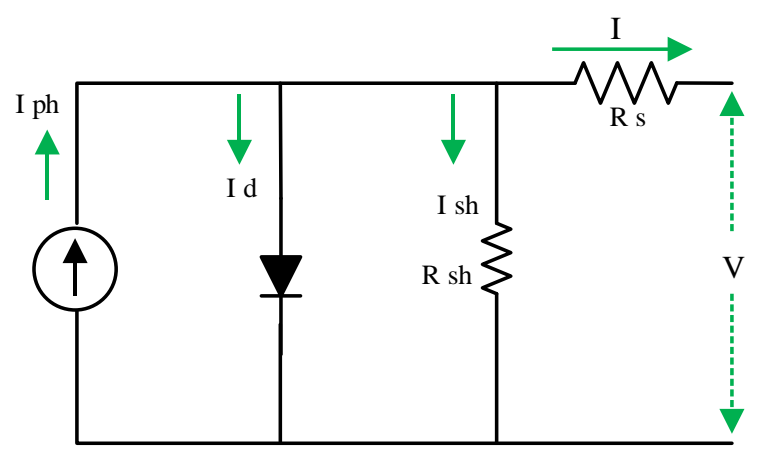

Figure 1: The equivalent circuit of the solar cell

The details of the used variables is as follows:

- $\mathrm{I}_{\mathrm{scr}}$ is rated solar current at normal conditions $\left(25^{\circ} \mathrm{C}\right)$

- $\mathrm{Ki}$ is temperature coefficient when circuit is in short circuit

- $\mathrm{G}$ is the solar cell irradiance in $\mathrm{W} / \mathrm{m}^{2}$

- $\Delta \mathrm{T}$ is $\left(\mathrm{T}-\mathrm{T}_{\text {ref }}\right)$ difference of temperature in operating and normal conditions

$\mathrm{I}=\mathrm{I}_{\mathrm{ph}}-\mathrm{I}_{\mathrm{o}}$

The output current $\mathrm{I}_{\mathrm{o}}$ is modelled in Eq. (3).

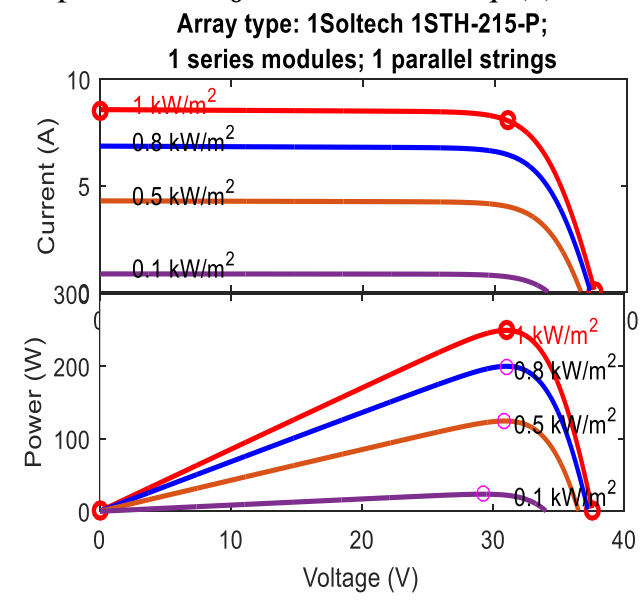

Figure 2: The PV and IV characteristics of the PV array 
Based on the non-linear characteristics of the temperature and solar irradiance, there exists the maximum power point (MPP) to every irradiance and temperature level. The Solar PV can deliver the maximum electrical power at its standard test conditions. The point $P_{m}$ represents the maximum value at I-V curve, $I_{m}$ shows the maximum current at which MPP exists, while, $V_{m}$ is the voltage at which MPP occurs. The IV and PV characteristics of the proposed solar array are shown in Fig 2.

\subsection{Sinusoidal Pulse Width Modulation}

In DC-AC inverters, the control of the MOSFET/IGBT switches is based on the modulation scheme. In square wave modulation, the fixed step size produces large number of harmonics in the output waveform. To overcome the problems associated with square wave modulation, the sinusoidal PWM is the effective alternative to reduce the harmonic eliminations. In SPWM, there are two signals; one is the reference signal which has the fundamental frequency ( 50 or $60 \mathrm{~Hz}$ ), the other one is the carrier signal that has higher frequency. When the amplitude of the reference signal is greater than the carrier signal, the output will be a positive pulse. Conversely, the larger amplitude of the carrier signal gives rise to the zero pulse. The SPWM for the proposed research is presented in Fig 3.

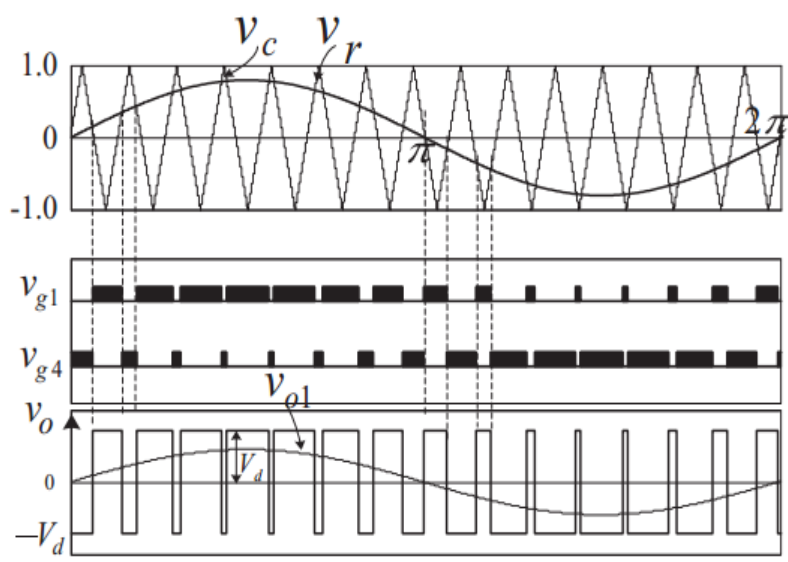

Figure 3: The Sinusoidal PWM Modulation Technique

Unlike square wave modulation, the width of all the pulses is not the same but it varies proportionally to the amplitude of a sine wave.

The sum of ON-time and OFF-time of the pulses describes the total period $\mathrm{T}$ as listed in Eq. (4) and the frequency is modelled in Eq. (5). The duty cycle (D) is the ratio of ON-time to the total time period $\mathrm{T}$ as written in Eq. (6) which is further used as the gate controller of the inverter switch. Hence, the output voltage across the inverter is acquired by changing the $\mathrm{D}$ of the gate signal.

Time Period, $\mathrm{T}=T_{O N}+T_{O F F}$

Frequency, $\mathrm{f}=1 /$ time period

Duty cycle, $\mathrm{D}=\frac{T_{O N}}{T_{O N}+T_{O F F}}$

The frequency modulation is the ratio of the reference signal and carrier signal is known as modulation index. The magnitude and the frequency of the output voltage is controlled with the help of modulation index. In amplitude modulation, the amplitude of a carrier signal is directly depending upon the amplitude of the reference signal. The output signal frequency and amplitude depend on the frequency and amplitude of the reference signal.

\subsection{Full Bridge Inverter Design}

The DC-AC converter is used to change direct current into AC. In the proposed PV system, the output of the solar is DC voltage. Hence, inverter is required to invert the DC voltage of the panel and make it useful for the residential ac load. Based on the nature of the input, the inverter is categorised into current source inverter (CSI) and voltage source inverter (VSI) (Converters n.d.). The CSI uses current as an input while VSI uses voltage at the input side of the inverter.

This paper is based on the single phase full bridge voltage source inverter that makes the solar power capable to operate the $\mathrm{AC}$ devices at homes. The schematic diagram of the proposed single phase full bridge inverter is demonstrated in Fig 4. The main difference between half bridge inverter and full bridge inverter is based on the maximum value of the output voltage. Besides, the half bridge inverter is simple, easy to implement and offers economical design by using fewer number of electronic switches. However, the magnitude of the output voltage is half as compared to input voltage that reduces the efficiency of the half bridge inverter. While, the full bridge inverter uses four switches but produces higher output peak voltage that is the same as the DC input supply voltage.

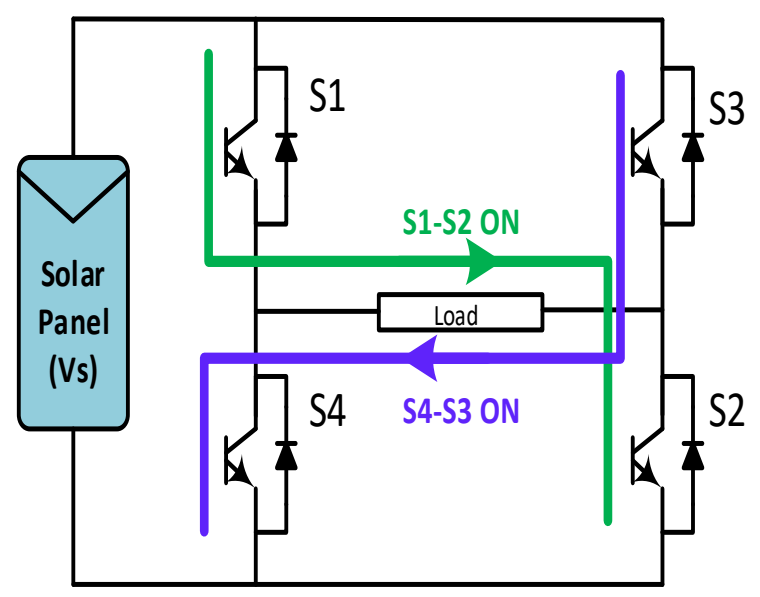

Figure 4: Full bridge inverter design for solar PV system

This paper focuses on the full bridge inverter because the average output is comparatively higher than the half bridge inverter. This higher voltage of full bridge inverter offers high efficiency as well (Younas 2019). The commonly used high frequency switches in inverters are; IGBTs, MOSFET, GTO etc. These are high frequency switching devices used in the power electronic domain because higher frequencies produce lower harmonic contents in the electronic circuits.

It is obvious from Fig 1 that the working of the proposed full bridge inverter is based on the four MOSFET switches which are; $S_{1}, S_{2}, S_{3}, S_{4} . S_{1}, S_{4}$ and $S_{2}, S_{3}$ are the complementary switches (Zhong and Hornik 2012). When $S_{1}$ and $S_{2}$ conducts, the current will flow through the switch $S_{1}$, load (left to right) and $S_{2}$. The conduction of $S_{3}$ and $S_{4}$ follow the current path through $S_{3}$, load (right to let) and $S_{4}$. It is noticed that the direction of current is reversed which justify the provision of the alternating current voltage at the load. The working principle 
and the output voltage with sequence of the switches are listed in Table 1.

Table 1: The switching sequence of the full bridge inverter

\begin{tabular}{|c|c|c|}
\hline ON Switches & OFF Switches & Output Voltage \\
\hline S1 & S3 & Vs \\
S2 & S4 & -Vs \\
\hline S3 & S1 & Complementary \\
S4 & Switches \\
S1-ON & S3 will OFF & $\begin{array}{c}\text { Can not be } \\
\text { Turned ON at } \\
\text { the same Time }\end{array}$ \\
\hline
\end{tabular}

In addition to four switches, the four freewheeling diodes D1, D2, D3 and D4 are also used that protect the device from the flow of leakage current during transition period of the switches.

\section{Results and Discussion}

In MATLAB, The 1soltech 1STH-215-P solar panel (see Table 2) is used to design the proposed standalone PV system. Initially, the DC voltage of the solar panel is converted to square wave AC voltage. Then, the R-LC circuit is used to transform the square wave AC to sinusoidal AC voltage. In order to get the desired $220 \mathrm{~V}$ sinusoidal AC voltage, the step up transformer (1:1800) is used to transform $12 \mathrm{~V} \mathrm{AC}$ to $220 \mathrm{~V} \mathrm{AC} \mathrm{(rms).} \mathrm{The}$ main components used for the simulation are; solar panel voltage, full bridge inverter, transformer, fixed pulses using delay circuit (Proteus), and SPWM (MATLAB). This section further proceed with the simulations of proteus and MATLAB respectively.

\subsection{Proteus based Simulation}

In proteus, DC voltage source is considered as the solar DC output voltage as shown in Fig. 5. Four high frequency MOSFETS are used to generate the sequence of fixed pulses with different time delays for the switches. The T1-T4 and T2T3 are complementary switches. The upper two switches T1-T3 and lower two switches T2-T4 cannot turn on at the same time otherwise there may be a short circuit to damage the device. The fix control pulses for the MOSFET switches are accomplished using time delay circuitry in order to avoid the complexity of the circuit. The square wave pulses are generated using the switches. The LC circuit is incorporated to make a sinusoidal waveform which is ideal for AC devices. The desired $220 \mathrm{~V}$ (rms) AC output voltage is accomplished with the help of the step up transformer. To generate sinewave at the output, LC network is desired which resonants at 7.2 KHz. Using Eq. (7) and Eq. (8), the value of the inductor is designed as $470 \mu \mathrm{H}$ and capacitor value is $1 \mu \mathrm{F}$ of the $\mathrm{LC}$ resonant frequency.

Frequency $=1 / 2 \pi \sqrt{ } \mathrm{LC}$

Frequency $=1 / 2 \pi \sqrt{ }\left(470 \mu \mathrm{H}^{*} 1 \mu \mathrm{F}\right)=7.34 \mathrm{kHz}$

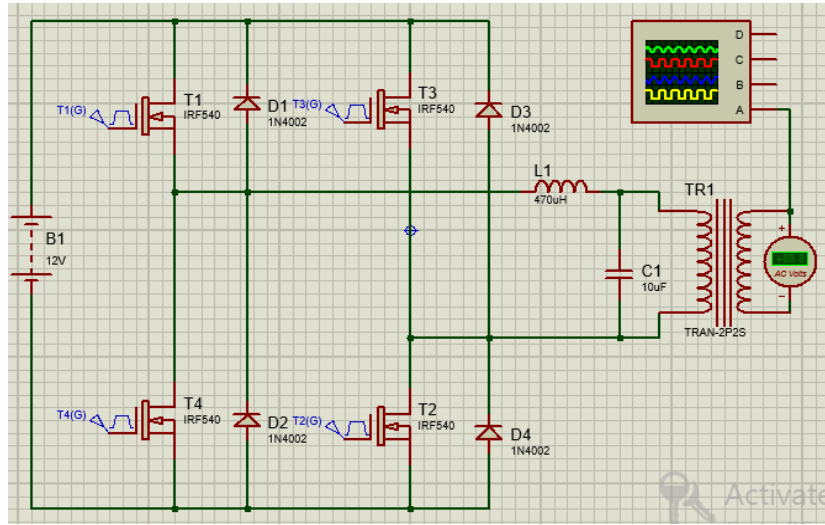

Figure 5: Proteus based simulation of the solar inverter

The sinusoidal ouput waveform of the full bridge inverter simulated in Proteus software is presented in Fig 6. For the $12 \mathrm{~V}$ DC supply which is converted to $12 \mathrm{~V} \mathrm{Ac}$ square wave is further converted to $310 \mathrm{~V}$ peak AC using step up transformer. In channel A the volt per division is selected on 20 value and the number of boxes in the sinusoidal waveform are aproximately 15.5. The total voltage at the output is modelled as;

$20 \mathrm{v} / \mathrm{div} * 15.5$ boxes $=310$ peak volt

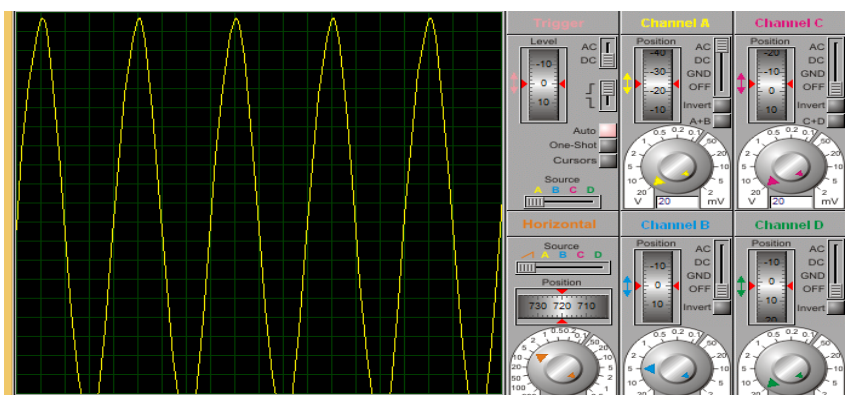

Figure 6: The sinusoidal output of the inverter in Proteus software

\subsection{MATLAB Simulink based Simulation}

In The complete simulation model of the proposed research paper which is comprised of; the solar panel, full bridge inverter and the step-up transformer is shown in Fig 7. The same valued electronic components are used in the Simulink model as were used in Proteus. The four switches combination is used that is followed by the LC circuit and the transformer. In this paper, boost converter is not involved hence, the transformer is serving as the step up converter and isolator between the source and the load as well.

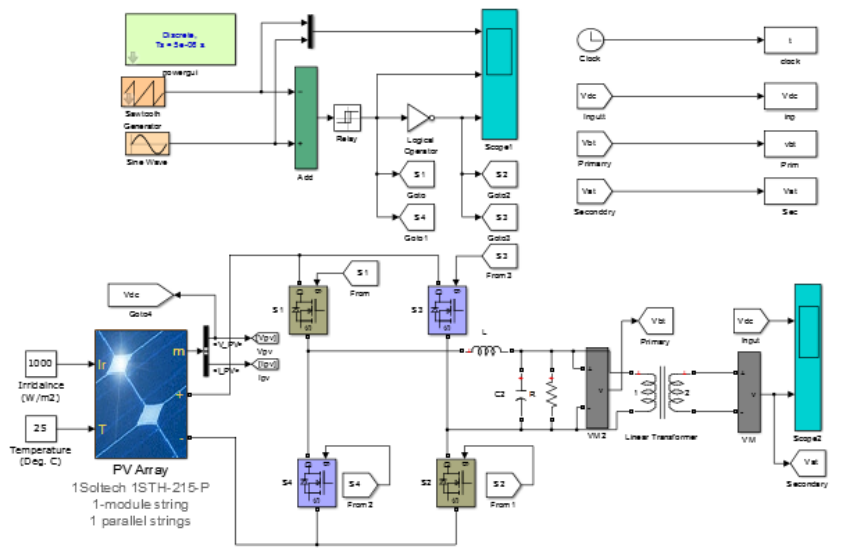

Figure 7: The simulation setup of the proposed model in MATLAB 
The 1soltech 1STH-215-P solar panel with 250 watt rated power having OCV $37.6 \mathrm{~V}$ is given to inverter. The specifications of the proposed solar panel used in MATLAB are listed in the Table 1.

Table 2: The specifications of the solar panel used in MATLAB

\begin{tabular}{|c|c|}
\hline Solar Panel Model & 1soltech 1STH-215-P \\
\hline Mamimum Power & 250 watt \\
\hline Light generated current & $8.57 \mathrm{~A}$ \\
\hline Cells Per Module & 60 \\
\hline Open Circuit Voltage & $37.6 \mathrm{~V}$ \\
\hline Short Circuit Current & $8.55 \mathrm{~A}$ \\
\hline
\end{tabular}

The inverter consists of the 4 MOSFET switches having switching frequency of $20 \mathrm{KHz}$. The SPWM is used as gate control signal for the MOSFET switches. The SPWM having the sinusoidal message signal of fundamental frequency is modulated with the triangular carrier signal having $20 \mathrm{KHz}$ frequency. The SPWM and the control signals generated for the full bridge inverter is demonstrated in Fig 8.

The switch S1 and S2 will turn ON at the same time. While, $\mathrm{S} 3$ and S4 will turn $\mathrm{ON}$ at the same time. In SPWM, the output will be high or 1 when the reference signal is greater than carrier signal otherwise output will be zero or low. The gate control pulses of the S1S2 and S3S4 are depicted in Fig 8.

The switch S1-S4 and S3-S2 are complementary in nature. The upper two switches S1-S3 and lower two switches S2-S4 cannot be turned $\mathrm{ON}$ at the same time.

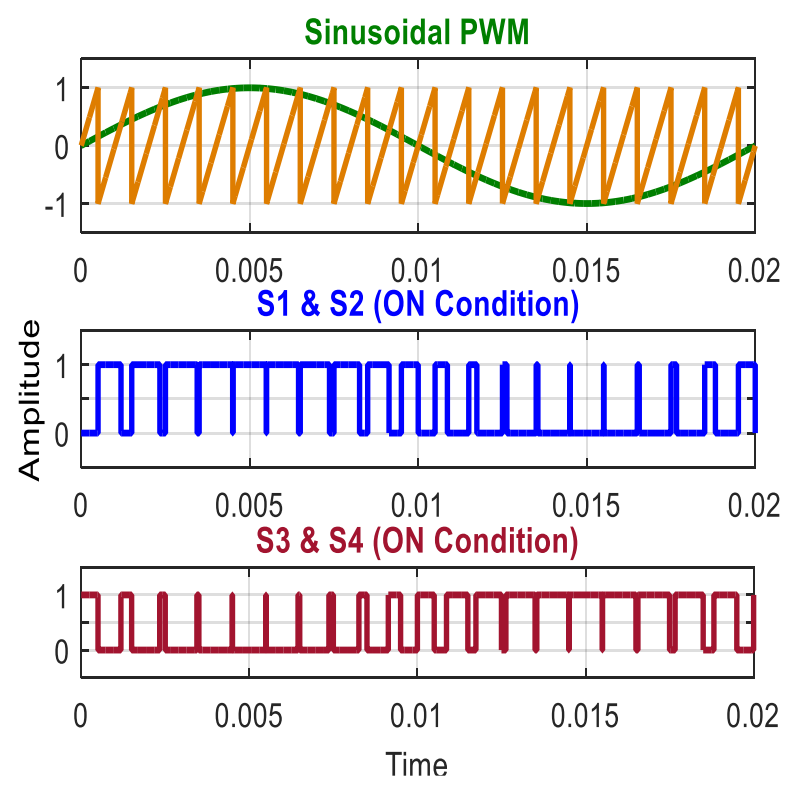

Figure 8: SPWM generated control pulses for inverter switches

The combination of S1 and S2 makes the current flow through the load in the direction from left to right as shown in Fig 3. Conversely, the S3 and S4 switch combination give rise to the current which flows through the load from right to left.

Initially, the four switch combination of inverter generates 12 V AC output voltage. Later, the step up transformer with a suitable turn ratio is used to get the desired $220 \mathrm{~V} \mathrm{AC}$ at the load as shown in Fig 10.

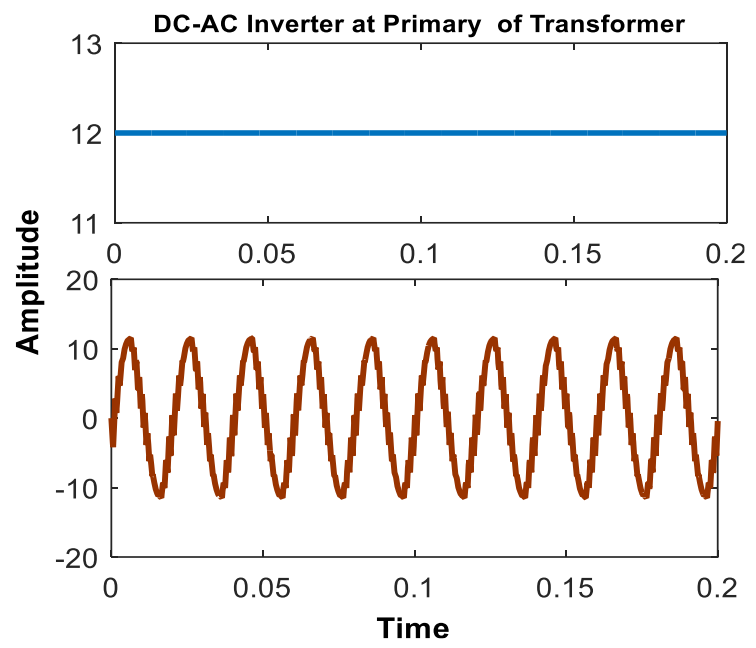

Figure 9: 12V DC-12V AC inversion at primary of the transformer

It is observed that the flow of current changes its direction means it is the 'alternating current'.
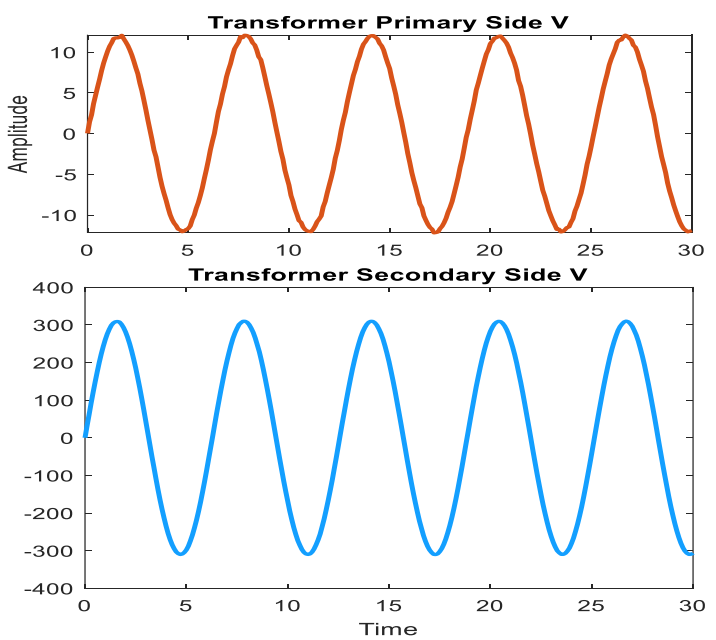

Figure 10: $12 \mathrm{~V}$ AC to $220 \mathrm{~V}$ (rms) AC inversion at secondary of the transformer $D C-A C$ inverters, the control of the MOSFET/IGBT

\section{Conclusion and Recommendations}

Considering the demerits of conventional energy and merits of the renewable energy, this paper encourages the deployment of renewable solar PV energy. The 215-watt solar PV array is considered, the full bridge inverter is used to accomplish the AC voltage from the panel that can be further used to power the AC devices. The simulation setup is performed in Proteus and MATLAB software with the difference of fixed pulses control signal (proteus) and variable control pulses based on SPWM (MATLAB). It is observed that the MATLAB offers better results in terms of efficiency, and it has a vast library which offers various facilities to link the simulations with the practical world.

In the future, it is planned to add the boost converter, harmonic analysis of the output, MPPT controller for the converter switches, and DC-AC full bridge inverter to make the supply useable for the AC load. 


\section{Acknowledge}

The undergraduate student authors from the COMSATS University Pakistan are thankful to the authors from Konya Technical University Turkey for their mentorship and technical support regarding this research article.

\section{References}

Alhafadhi, Liqaa, and Jiashen Teh. 2020. "Advances in Reduction of Total Harmonic Distortion in Solar Photovoltaic Systems: A Literature Review." International Journal of Energy Research 44(4):2455-70.

Converters, A. C. n.d. "Lesson Introduction to Voltage Source Inverters." 1-14.

Kumar, Raj, S. K. Singh, and others. 2018. "Solar Photovoltaic Modeling and Simulation: As a Renewable Energy Solution." Energy Reports 4:701-12.

Li, Dexin, and Pai H. Chou. 2004. "Maximizing Efficiency of Solar-Powered Systems by Load Matching." Pp. 162-67 in Proceedings of the 2004 International Symposium on Low Power Electronics and Design (IEEE Cat. No. 04TH8758).

Mousazadeh, Hossein, Alireza Keyhani, Arzhang Javadi, Hossein Mobli, Karen Abrinia, and Ahmad Sharifi. 2009. “A Review of Principle and Sun-Tracking Methods for Maximizing Solar Systems Output." Renewable and
Sustainable Energy Reviews 13(8):1800-1818.

Sastry, Jyoti, Panagiotis Bakas, Hongrae Kim, Lei Wang, and Antonios Marinopoulos. 2014. "Evaluation of Cascaded HBridge Inverter for Utility-Scale Photovoltaic Systems." Renewable Energy 69:208-18.

System, Power. 2016. "An Intelligent MPPT Design of DC-DC Converter for PV in a PV / SC Hybrid 290 . An Intelligent MPPT Design of DC-DC Converter for PV in a PV / SC Hybrid Power System." (November).

Taherbaneh, Mohsen, A. H. Rezaie, H. Ghafoorifard, K. Rahimi, and M. B. Menhaj. 2010. "Maximizing Output Power of a Solar Panel via Combination of Sun Tracking and Maximum Power Point Tracking by Fuzzy Controllers." International Journal of Photoenergy 2010.

Younas, Umair. 2019. "Nevşehir Bilim ve Teknoloji Dergisi The Implementation of Effective Modulation Schemes to Improve the Power and Harmonic." 8:125-35. doi: 10.17100/nevbiltek.559465.

Younas, Umair, Bayram Akdemir, and Ahmet Afsin Kulaksiz. n.d. "Modeling and Simulation of a Grid-Connected PV System under Varying Environmental Conditions." International Journal of Energy Applications and Technologies 6(1):17-23.

Zhong, Qing-Chang, and Tomas Hornik. 2012. Control of Power Inverters in Renewable Energy and Smart Grid Integration. Vol. 97. John Wiley \& Sons. 